\title{
MSH6 Gene Mutation
}

National Cancer Institute

\section{Source}

National Cancer Institute. MSH6 Gene Mutation. NCI Thesaurus. Code C118395.

A change in the nucleotide sequence of the MSH6 gene. 